\title{
Defoliation Effects on Bromus tectorum Seed Production: Implications for Grazing
}

\author{
Kara Hempy-Mayer ${ }^{1}$ and David A. Pyke ${ }^{2}$
}

Authors are ${ }^{1}$ Pest Survey Coordinator, Colorado Department of Agriculture-Plant Industry Division, Lakewood, CO 80215, USA; and ${ }^{2}$ Research
Rangeland Ecologist, US Geological Survey, Forest and Rangeland Ecosystem Science Center, Corvallis Research Group, Corvallis, OR 97331, USA.

\begin{abstract}
Cheatgrass (Bromus tectorum L.) is an invasive annual grass that creates near-homogenous stands in areas throughout the Intermountain sagebrush steppe and challenges successful native plant restoration in these areas. A clipping experiment carried out at two cheatgrass-dominated sites in eastern Oregon (Lincoln Bench and Succor Creek) evaluated defoliation as a potential control method for cheatgrass and a seeding preparation method for native plant reseeding projects. Treatments involved clipping plants at two heights (tall $=7.6 \mathrm{~cm}$, and short $=2.5 \mathrm{~cm}$ ), two phenological stages (boot and purple), and two frequencies (once and twice), although purple-stage treatments were clipped only once. Treatments at each site were replicated in a randomized complete block design that included a control with no defoliation. End-of-season seed density (seeds $\cdot \mathrm{m}^{-2}$ ) was estimated by sampling viable seeds from plants, litter, and soil of each treatment. Unclipped control plants produced an average of approximately 13000 and 20000 seeds $\cdot \mathrm{m}^{-2}$ at Lincoln Bench and Succor Creek, respectively. Plants clipped short at the boot stage and again $2 \mathrm{wk}$ later had among the lowest mean seed densities at both sites, and were considered the most successful treatments (Lincoln Bench: $\mathrm{F}_{6,45}=47.07, P<0.0001$; Succor Creek: $\mathrm{F}_{6,40}=19.60, P<0.0001$ ). The 95\% confidence intervals for seed densities were 123-324 seeds $\cdot \mathrm{m}^{-2}$ from the Lincoln Bench treatment, and 769-2 256 seeds $\cdot \mathrm{m}^{-2}$ from the Succor Creek treatment. Literature suggests a maximum acceptable cheatgrass seed density of approximately $330 \mathrm{seeds} \cdot \mathrm{m}^{-2}$ for successful native plant restoration through reseeding. Thus, although this study helped pinpoint optimal defoliation parameters for cheatgrass control, it also called into question the potential for livestock grazing to be an effective seed-bed preparation technique in native plant reseeding projects in cheatgrass-dominated areas.
\end{abstract}

\section{Resumen}

"Cheatgrass" (Bromus tectorum L.) es un zacate anual invasor que crea poblaciones casi puras en áreas de los valles de la estepa de "sagebrush" y desafía la restauración exitosa de estas áreas a con plantas nativas. Se condujo un experimento de cortes en dos sitios dominados por "Cheatgrass" en el este de Oregon (Lincoln Bench y Succor Creek) para evaluar la defoliación como un método potencial de control del "Cheatgrass" y un método de preparación de la cama de siembra para los proyectos de resiembra de plantas nativas. Los tratamientos involucraron dos alturas de corte (alto $=7.6 \mathrm{~cm}$ y corto $=2.5 \mathrm{~cm}$ ), dos etapas fenológicas (embuche y estado masoso) y dos frecuencias (una o dos veces), aunque en la etapa de maduración los tratamientos fueron cortados solo una vez. En cada sitio los tratamientos se repitieron bajo un diseño de bloques completos al azar y se incluyó un tratamiento control sin defoliación. Al final de la estación se estimó la densidad de semillas (semillas $\cdot \mathrm{m}^{-2}$ ) en cada tratamiento muestreando las semillas viables de las plantas, el matillo y el suelo. Las plantas del tratamiento control produjeron en promedio aproximadamente 13000 y 20000 semillas $\cdot \mathrm{m}^{-2}$ en los sitios Lincoln Bench y Succor Creek, respectivamente. Las medias de densidad de semilla de las plantas defoliadas a la altura corta en la etapa de embuche y de nuevo dos semanas después, estuvieron entre las más bajas y fueron considerados los tratamientos mas exitosos (Lincoln Bench $\mathrm{F}_{6,45}=47.07, P<0.0001$; Succor Creek $\left.\mathrm{F}_{6,40}=19.60, P<0.0001\right)$. Los intervalos de confianza al $95 \%$ para las densidades de semilla fueron $123-324$ semillas $\cdot \mathrm{m}^{-2}$ en los tratamientos de Lincoln Bench y 769-2 256 semillas $\cdot \mathrm{m}^{-2}$ en los de Succor Creek. La literatura sugiere una densidad máxima aceptable de semillas de "Cheatgrass" de aproximadamente 330 semillas $\cdot \mathrm{m}^{-2}$ para lograr una restauración exitosa con plantas nativas mediante resiembra. Así, mientras este estudio ayudó a precisar los parámetros óptimos de defoliación para el control del "Cheatgrass", también cuestiona el potencial del apacentamiento con ganado para ser una técnica efectiva de preparación de la cama de siembra en los proyectos de resiembra con plantas nativas de las áreas dominadas por "Cheatgrass".

Key Words: Cheatgrass, clipping, grazing, livestock, native plant restoration, weed control

\section{INTRODUCTION}

Research was supported by the US Geological Survey Coordinated Intermountain Restoration Project, Oregon State University, and by the Cooperative State Research, Education, and Extension Service, US Department of Agriculture, under Agreement 2001-52103-11322.

At the time of the research, Hempy-Mayer was graduate research assistant, Dept of Botany and Plant Pathology, Oregon State University, Corvallis, OR, USA.

Correspondence: Dr David A. Pyke, US Geological Survey Forest and Rangeland Ecosystem Science Center, 3200 SW Jefferson Way, Corvallis, OR 97331, USA. Email: david_a_pyke@usgs.gov

Manuscript received 21 February 2007; manuscript accepted 26 October 2007.
Cheatgrass (Bromus tectorum L.) has been rapidly spreading into western rangelands of the United States since its introduction by settlers in the late 1800s (Mack 1986). It is a highly competitive exotic annual grass that has become dominant in large segments of the Intermountain West, replacing much of the perennial-dominated sagebrush steppe with a near monoculture of annual grass (Pellant and Hall 1994). Concern over the consequences of this drastic landscape alteration has 
motivated attempts to reestablish native plants on cheatgrassdominated sites using artificial seeding and transplanting techniques (Pellant 1990; Sanders 1994; Allcock et al. 2006). Part of the challenge of carrying out a successful revegetation project is competition with weeds such as cheatgrass, which has been identified as one of the major causes of seeding failures of native plants in the Intermountain West (Hull and Pearse 1943; Stark et al. 1946; Klemmedson and Smith 1964; Sanders 1994; Whisenant 1999). Thus, finding an effective cheatgrass control method is needed for successful native plant restoration.

Mosley (1996) makes a strong case for using intensive sheep grazing as a method for controlling cheatgrass in rangelands. Other studies have considered the possibility of using sheep or cattle for this purpose (Booysen et al. 1963; Miller et al. 1994; Vallentine and Stevens 1994). There is strong qualitative and quantitative evidence that grazing could be effective in reducing the abundance of cheatgrass in the landscape (Daubenmire 1940; Finnerty and Klingman 1962; Mack and Pyke 1984; Pyke 1986, 1987; Tausch et al. 1994; Mosley 1996). Given the costs of other cheatgrass control methods such as herbicide applications, mechanical treatments, and burning (Pellant 1990; Mosley 1996; Whisenant 1999), and given that livestock will use cheatgrass as forage (Klemmedson and Smith 1964)—helping offset cheatgrass control costs as well as benefiting local ranchers-livestock as a biological control could provide an effective and less expensive alternative or supplement to these control methods. Furthermore, the evidence that livestock could be used to reduce cheatgrass in rangelands suggests that it could be used even more extensively to prepare an area for the reseeding of native plants-a goal requiring intensive cheatgrass control methods that has not been directly addressed in the previous studies. Additional evidence regarding treatment parameters and effectiveness in reducing cheatgrass seed densities would be useful to those planning native plant reseeding projects who are interested in using grazing as a cheatgrass-control method.

The objectives of our study were as follows: to pinpoint the optimal defoliation (clipping) timing, intensity (i.e., stubble height), and frequency for maximum seed reduction, and to compare these seed reductions to the projected reductions needed to prepare an effective seedbed for native reseeding projects in semiarid environments. We measured the effects of two levels each of defoliation timing, intensity, and frequency on the seed reduction that can be achieved over a season. Secondary objectives were to quantify cheatgrass phenologies and the amount of viable seed present at the time of each clipping treatment, the effectiveness of treatments in removing inflorescences, and how much biomass was removed in each clipping in consideration of potential livestock forage. We recognize that clipping does not adequately simulate livestock defoliation and grazing effects (e.g., saliva, excretion, trampling, and plant selection effects). However, clipping can provide an index of the necessary timing and intensity that might be necessary should livestock be used to control cheatgrass.

\section{METHODS}

\section{Study Site}

Experiments were carried out in 2003 at two fenced, 4-acre sites on Bureau of Land Management land in Malheur
County, Oregon, referred to as Lincoln Bench (lat $43^{\circ} 54^{\prime} \mathrm{N}$, long $117^{\circ} 9^{\prime} \mathrm{W}$ ) and Succor Creek (lat $43^{\circ} 34^{\prime} \mathrm{N}$, long $\left.117^{\circ} 6^{\prime} \mathrm{W}\right)$. Both sites were selected nonrandomly based on their location inside a region that was historically western Intermountain sagebrush steppe (West 1983) and that is currently dominated by cheatgrass $(\geq 60 \%$ of the cover composition) with native plants representing less than $1 \%$ of the cover. Estimated precipitation for the year of the study (September 2002-August 2003) was $241 \mathrm{~mm}$ and $218 \mathrm{~mm}$ at Lincoln Bench and Succor Creek, respectively-about $85 \%$ of the historical average (PRISM Group 2004). Seasonal volumetric soil moisture measured using a time-domain reflectometer (Trase 2100, SoilMoisture Equipment Corporation, Santa Barbara, CA) and averaged over six readings between 26 April and 8 June were similar between sites with values of approximately $10.3 \%(95 \% \mathrm{CI}=9.4 \%-11.3 \%)$ at Lincoln Bench, and $12.0 \%(95 \% \mathrm{CI}=11.0 \%-13.1 \%)$ at Succor Creek. Basic soil descriptions were completed for each site in June 2003. Soil surveys of this area are incomplete, so soil descriptions were obtained with the help of a soil scientist (S. Egbert, personal communication, June 2003). Upper soil horizons at both sites consisted of a silty clay loam over a silty clay, with the silty clay loam extending into $11 \mathrm{~cm}$ at Lincoln Bench, and $5 \mathrm{~cm}$ at Succor Creek (for more detailed descriptions see Mayer 2004).

\section{Experimental Design}

Experimental treatments were combined in a factorial arrangement and were located in nine randomly placed blocks using a randomized complete block design, for a sample size of nine for each treatment at each site. Each experimental unit consisted of a $1-\mathrm{m}^{2}$ treatment area surrounded by a $1-\mathrm{m}$ buffer. Blocks falling on areas with extremely low cheatgrass density were not used and new blocks were randomly selected from within the site.

Treatments included clipping of cheatgrass at the onset of two phenological stages (boot $[\mathrm{B}]$ and purple $[\mathrm{P}]$ stages), two clipping heights (short $[\mathrm{S}]=2.5 \mathrm{~cm}$; tall $[\mathrm{T}]=7.6 \mathrm{~cm}$ ), two clipping frequencies (once [1] and twice [2]), and a control of no clipping $(\mathrm{C}$; for instance, the short boot treatment clipped twice is SB2, the short purple treatment is SP, and so on). The B stage was the moment when inflorescences were beginning to emerge from the sheath, and corresponded with the late spring clippings applied by Tausch et al. (1994). The P stage was the moment when caryopses and/or glumes turned red or purple, which roughly corresponds to the 'dough' stage referred to by Hulbert (1955). By using two easily recognizable phenological stages, we were able to examine the effect of defoliation on cheatgrass from the time of increased susceptibility to grazing to its reduced palatability for livestock-two points that are correlated with the B and P stages, respectively (Klemmedson and Smith 1964). First clippings occurred when the tallest stems of the majority of plants in treatment plots were at the appropriate phenological stage. The taller clipping height of $7.6 \mathrm{~cm}$ was chosen to test Mosley's (1996) recommendation that cheatgrass can be controlled by grazing to this stubble height with sheep, even though sheep are capable of grazing cheatgrass to about $1.0 \mathrm{~cm}$ (Cook and Harris 1952). The shorter height of $2.5 \mathrm{~cm}$ is considered a reasonable height to which cattle could graze $(\mathrm{M}$. 
Pellant, personal communication, February 2002). Second clippings were conducted $2 \mathrm{wk}$ after the first to account for potential regrowth through tiller development, and were also recommended by Mosley (1996). Second clippings of P treatments were not completed as planned because the growing season ended before they could be achieved. Thus, there were a total of seven clipping treatments.

Treatments were conducted by clipping all plants in the $1-\mathrm{m}^{2}$ treatment plot to the appropriate height with scissors and bagging the clipped material. Plants in the buffer area were clipped to approximately the same height as the inner treatment plot either with a mower or by hand with scissors. The first $B$ clippings occurred on 26 April and the second on 10 May. The first $\mathrm{P}$ clippings occurred on $24 \mathrm{May}$, and the experiment was terminated and samples harvested $1 \mathrm{wk}$ after the $\mathrm{P}$ clipping when seeds were mature and had begun to disperse.

\section{Sampling}

Treatment Phenologies. Sites were monitored closely throughout the season to determine treatment dates. To evaluate phenological status at the time of each treatment, phenology surveys were completed within four $39-\mathrm{cm}^{2}$ subsamples placed randomly within each treatment plot. The proportion of plants in various phenological stages (preboot, B, and postboot for the two early-season clippings, and green, $\mathrm{P}$, and tan for the lateseason clipping) were averaged across the four subsamples. For the first B clippings, phenological status had to be approximated from surveys completed 1 wk before and after treatments were applied due to time constraints, as well as from visual inspection at the time of the treatments. For the second $\mathrm{B}$ and $\mathrm{P}$ clippings, surveys were conducted the day before treatments were applied. To quantify the average proportion of inflorescences removed, similar surveys were conducted $1 \mathrm{wk}$ after treatments were applied.

Seed Densities. Cheatgrass seed density was estimated at two general timeframes (midseason and end-of-season) during the season of growth. For midseason seed density, we quantified the amount of seed produced by actively growing plants to determine how much viable seed was present at the time of treatment. For end-of-season seed density, we quantified the seed produced by plants along with the seed existing in the litter and soil seed bank to determine how much seed would be available for the following season's growth. Estimates of midseason seed density were collected at times of clippings during the late-spring growing season (26 April, 10 May, and 24 May 2003) using clipped plants on experimental units of three randomly chosen blocks at each site. End-of-season seeds were obtained on 31 May 2003 by clipping and collecting all plants retaining an inflorescence in the center $0.25-\mathrm{m}^{2}$ area of each treatment plot. Litter and soil samples were taken to quantify both persisting and newly deposited seed. Although the soil seed bank is often exhausted annually (Hulbert 1955; Pyke 1994), the litter seed bank density can average 1200 seeds $\cdot \mathrm{m}^{-2}$ at the end of the growing season (Young and Evans 1975). Litter was collected from two randomly placed $0.01-\mathrm{m}^{2}$ quadrats $\left(12.5 \%\right.$ of the plot area) from the center $0.25-\mathrm{m}^{2}$ area after plants had been removed. Soil samples consisted of the top $3 \mathrm{~cm}$ of soil under each litter sample.
In the lab, seeds were collected by stripping them from plants by hand. Plants infested with smut (Ustilago bullata) were not counted because these plants rarely produce viable seeds (Fisher and Holton 1957; Falloon 1979; Pyke 1983). Seeds were separated from litter samples using a screen. For end-of-season density, plant and litter seed samples were further cleaned of chaff and empty florets by running them through a pneumatic scarifier (Hoffman Manufacturing, Albany, OR) and then weighed. Seed numbers were estimated using either average seed weights for large samples, or counted directly in samples with equal to or fewer than 200 seeds.

Seed viability for samples was estimated 4 mo after collection to ensure adequate after-ripening using Association of Official Seed Analysts (Association of Official Seed Analysts 2002a, $2002 \mathrm{~b}$ ) protocols. Two hundred seeds were randomly selected from each sample and divided into subsamples of 50. Each subsample was placed into one of four petri dishes lined with germination paper. Incubation was carried out in the dark for $10 \mathrm{~d}$ at $25^{\circ} \mathrm{C}$, which was deemed adequate for complete germination of cheatgrass seeds during preliminary tests. Seeds were considered germinated when a seedling developed a root and shoot, with the shoot located at least halfway up the hypocotyl. Abnormal seedlings, seeds infested with fungus, and ungerminated seeds were considered nonviable (based on evidence of nonviability from tetrazolium chloride tests of nongerminated seeds, which supported reports that viable cheatgrass seeds often achieve $100 \%$ germination following an after-ripening period of 4 mo; Beckstead et al. 1993; Pyke and Novak 1994). Germination percentages were then multiplied by the estimated seed numbers to determine the number of viable seeds per sample. Viable seeds were estimated from soil samples by spreading the soil into sand-filled trays, watering the soil, and counting germinated seeds. Plant, litter, and soil seed numbers were then summed to estimate the total number of viable seeds per square meter for each experimental unit.

Because it was not possible in this study to estimate the amount of preexisting seed in the soil and litter seed bank, some proportion of the total seed density may have been from the previous season. Evidence suggests that cheatgrass seed can form a persistent seed bank extending over $1 \mathrm{yr}$, although the amount of persistent seed would presumably be relatively small given the inherently high germination rates of cheatgrass seed (Pyke 1994; Pyke and Novak 1994). Because viable seeds are potential plants in future generations and potential competitors with seedlings in restoration projects, we have elected to combine seed bank densities with the seed production in the current year to report the total potential cheatgrass population as a total seed density (

Biomass Removed. The clipped plant matter removed from each experimental unit following a clipping treatment was oven-dried at $50^{\circ} \mathrm{C}$ for $72 \mathrm{~h}$ and weighed to estimate plant biomass $\left(\mathrm{g} \cdot \mathrm{m}^{-2}\right)$. Estimates were averaged across the nine blocks to quantify the biomass removed in each treatment.

\section{Analysis}

Because sites were selected nonrandomly, they were not considered replicates and therefore statistical analysis was done separately for each site with blocks within sites being the replicates. Analysis of variance (ANOVA; Proc Mixed; SAS 
Table 1. Median end-of-season cheatgrass seed density (seeds $\cdot \mathrm{m}^{-2}$, a combination of seed density on current plants and soil-litter seed banks) at Succor Creek and Lincoln Bench, with 95\% confidence intervals of the median in parentheses. Estimates with the same letters within sites are not significantly different $(P>0.05)$.

\begin{tabular}{|c|c|c|}
\hline Treatment $^{1}$ & Lincoln Bench & Succor Creek \\
\hline SB2 & 200a (123-324) & 1317a (769-2 256) \\
\hline SP & $1203 b(741-1953)$ & 1104a (693-1759) \\
\hline SB1 & 1354b (857-2 137) & 7739b (4 987-12010) \\
\hline TB2 & $1831 b(1160-2890)$ & $6517 b(4089-10386)$ \\
\hline TP & $2427 b(1537-3831)$ & $6098 b(3826-9720)$ \\
\hline TB1 & 17 020c (10 488-27 623) & $16908 b(10608-26947)$ \\
\hline C & 19547c (12381-30 861) & 12795b (8 028-20393) \\
\hline
\end{tabular}

${ }^{1} \mathrm{SB} 1$ indicates short boot once; SB2, short boot twice; TB1, tall boot once; TB2, tall boot twice; SP, short purple; TP, tall purple; and C, control.

1999) was used to test the null hypotheses of no difference in end-of-season cheatgrass seed density among treatments. If ANOVA tests were significant, all pair-wise comparisons were made between treatments using the Tukey-Kramer adjustment for multiple comparisons. The significance level was set at 0.05. Normality and equal variance were satisfied using a log transformation. Resulting means were back-transformed to provide estimates of the medians and the $95 \%$ confidence intervals (CIs) of the medians of seed density, and multiplicative treatment effects were reported. Because midseason seed density, proportion of inflorescences removed, pretreatment phenology, and proportion of biomass removed were meant to provide descriptive information, means and 95\% CI were reported, but significance tests were not run.

\section{RESULTS}

\section{Seed Density}

All treatments produced viable seeds at the end of the season, and the effect of clipping on seed numbers from the plants, litter, and soil differed significantly among treatments at both Lincoln Bench $\left(\mathrm{F}_{6,45}=47.07, P<0.0001\right)$ and Succor Creek $\left(\mathrm{F}_{6,40}=19.60, P<0.0001 ;\right.$ Table 1$)$. At Lincoln Bench, all treatments except those clipped once at the TB $(7.6 \mathrm{~cm})$ stage were significantly less than the control, whereas at Succor Creek, only those clipped at the SP $(2.5 \mathrm{~cm})$ stage, or those clipped twice at the SB stage (SB2) were significantly less than the control. The SB2 treatment produced the fewest seeds at Lincoln Bench, with median seed density of the control approximately 98 times greater $(P<0.0001)$. Both SB2 and SP produced the fewest seeds at Succor Creek, with median seed density of the control approximately 10 and 12 times greater, respectively $(P<0.0001)$. Overall, the $S$ clippings after the initial $\mathrm{B}$ stage and nearing the $\mathrm{P}$ stage were the most effective in reducing cheatgrass seed densities. The $\mathrm{T}$ treatments clipped early in the season had no effect on seed density relative to the control.

Although small sample sizes and high variability made statistical analysis of midseason seed density difficult, both observations and values calculated from samples clearly indicated that a substantial number of mature seeds were present at the time of the $\mathrm{P}$ clippings on 25 May (Table 2;
Table 2. Midseason cheatgrass seed production (seeds $\cdot \mathrm{m}^{-2}$ ) on live plants growing at the time of each clipping treatment at Lincoln Bench and Succor Creek. 95\% confidence intervals are in parentheses.

\begin{tabular}{cccc}
\hline Treatment $^{1}$ & Date & Lincoln Bench & Succor Creek \\
\hline SB1 & 26 April & $0(0)$ & $0(0)$ \\
TB1 & 26 April & $0(0)$ & $0(0)$ \\
SB2 & 10 May & $8(0-19)$ & $3(3-3)$ \\
TB2 & 10 May & $24(0-59)$ & $6(0-13)$ \\
SP & 24 May & $11986(7106-16866)$ & $3211(0-7709)$ \\
TP & 24 May & $10643(3238-18048)$ & $8404(5080-11727)$ \\
\hline
\end{tabular}

${ }^{1} \mathrm{SB} 1$ indicates short boot once; SB2, short boot twice; TB1, tall boot once; TB2, tall boot twice; SP, short purple; and TP, tall purple.

calculated seed densities for SP ranged from 7617 to 16240 seeds $\cdot \mathrm{m}^{-2}$ at Lincoln Bench, and 605-7786 seeds $\cdot \mathrm{m}^{-2}$ at Succor Creek). At the time plants were clipped during the second boot stage on 10 May, plants were producing some viable seeds (calculated seed densities ranged from 0-42 seeds $\cdot \mathrm{m}^{-2}$ at Lincoln Bench, and 2-13 seeds $\cdot \mathrm{m}^{-2}$ at Succor Creek). No viable seeds were found in samples taken at the time of the first B clippings on 27 April.

\section{Inflorescence Removal}

Posttreatment surveys indicated that $S$ clipping treatments at Lincoln Bench tended to remove a majority of the inflorescences, as did the SP and TP treatments at both sites (Fig. 1). The first TB treatment scarcely removed any inflorescences. No treatment achieved $100 \%$ removal or, if there was regrowth, no treatment was able to completely remove or prevent development of inflorescences.

\section{Plant Phenologies}

Pretreatment surveys indicated that clippings occurred when the majority of plants were at the appropriate phenological

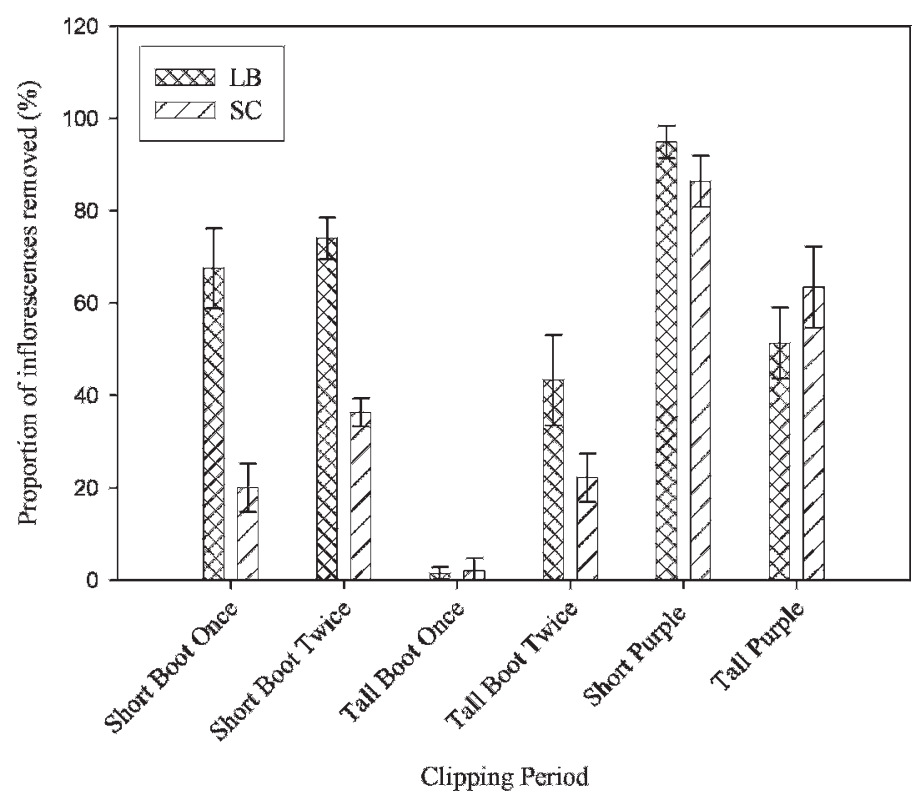

Figure 1. Proportion of cheatgrass inflorescences removed by clipping treatments at Lincoln Bench (LB) and Succor Creek (SC). Bars indicate $95 \%$ confidence intervals. 
Table 3. Cheatgrass biomass $\left(\mathrm{g} \cdot \mathrm{m}^{-2}\right)$ removed by clipping treatments at Lincoln Bench and Succor Creek. 95\% confidence Intervals are in parentheses.

\begin{tabular}{cccc}
\hline Treatment $^{1}$ & Date & Lincoln Bench & Succor Creek \\
\hline SB1 & 26 April & $36.5(29.5-43.4)$ & $11.7(6.6-16.7)$ \\
SB2 & 26 April & $30.7(24.2-37.2)$ & $9.1(4.4-13.9)$ \\
& 10 May & $9.4(4.8-13.9)$ & $9.2(6.9-11.5)$ \\
TB1 & 26 April & $1.6(0.3-2.9)$ & $1.2(0.3-2.2)$ \\
TB2 & 26 April & $1.2(0.3-2.0)$ & $0.8(0.2-1.4)$ \\
& 10 May & $37.5(28.0-47.0)$ & $15.9(8.6-23.3)$ \\
SP & 24 May & $103.7(81.5-126.0)$ & $29.5(18.8-40.3)$ \\
TP & 24 May & $62.1(46.3-77.9)$ & $45.4(33.8-57.0)$ \\
\hline
\end{tabular}

${ }^{1} \mathrm{SB} 1$ indicates short boot once; SB2, short boot twice; TB1, tall boot once; TB2, tall boot twice; SP, short purple; and TP, tall purple.

stages (i.e., first B and P), as intended, but with other stages present in substantial proportions as well. Surveys completed $1 \mathrm{wk}$ prior to the first B-stage clipping (20 April) found that a majority of plants were in the preboot stage $(87 \%$ of plants \pm 4 Lincoln Bench, $76 \%$ of plants $\pm 5 \%$ Succor Creek, mean $\pm 95 \% \mathrm{CI}$ ), with the remaining plants in the B stage. We determined that the majority of plants had progressed to the $\mathrm{B}$ stage by a visual inspection at both sites by 26 April, at which point the first $\mathrm{B}$ treatments were initiated. In the second SB clippings on 10 May, most of the plants were in the preboot stage $(49 \% \pm 15 \%$ [Lincoln Bench], $43 \% \pm 6 \%$ [Succor Creek]), with postboot being the next most common stage $(28 \% \pm 11 \%$ [Lincoln Bench], 32\% $\pm 10 \%$ [Succor Creek]). Conversely, the second $\mathrm{TB}$ clippings of 10 May were dominated by postboot plants $(93 \% \pm 3 \%$ [Lincoln Bench], $74 \% \pm 10 \%$ [Succor Creek]), but still had plants present in both of the earlier stages (e.g., $\mathrm{B}=5 \% \pm 2 \%$ [Lincoln Bench], $18 \% \pm 8 \%$ [Succor Creek]). When P clippings were carried out on 24 May, all plants were postboot with the majority in the $\mathrm{P}$ stage $(82 \% \pm 5 \%$ [Lincoln Bench], $56 \% \pm 11 \%$ [Succor Creek]), but with some still green $(3 \% \pm 2 \%$ [Lincoln Bench], $31 \% \pm 10 \%$ [Succor Creek]), and some that had already senesced $(14 \% \pm 6 \%$ [Lincoln Bench], $13 \% \pm 8 \%$ [Succor Creek]).

\section{Biomass Removed}

$P$ treatments, the first of the SB treatments, and the second of the TB treatments removed substantial amounts of biomass, particularly at Lincoln Bench (Table 3). The first of the SB treatments also removed a substantial amount of biomass, but only at Lincoln Bench. The second of the SB treatments and the first of the TB treatments removed very little biomass at both sites, with the estimates of biomass removed from the first and second SB treatments tending to be very similar at Succor Creek.

\section{DISCUSSION}

Conversions of sagebrush steppe to near-monocultures of cheatgrass have become common in the Intermountain West of the United States. Successful restoration of these lands will require the reintroduction of desirable perennial plants (Pellant 1990). Because cheatgrass is known to compete with desirable species (Hull and Pearse 1943; Stark et al. 1946; Klemmedson and Smith 1964; Sanders 1994; Whisenant 1999), native plant seedling survival will require sufficient reductions in cheatgrass seed densities and subsequent plant populations to levels where competition for resources will not impair desired-plant establishment. Using the results from our clipping studies conducted as field experiments in near-monocultures of cheatgrass, we can project a combination of defoliation times, intensities, and frequencies of defoliation that will significantly reduce cheatgrass seed densities in one growing season under similar environmental conditions. Overall, clipping plants to a height of $7.6 \mathrm{~cm}$ and clipping once in the B stage were relatively ineffective at reducing cheatgrass seed densities. The most effective defoliation treatment was clipping plants twice to a height of $2.5 \mathrm{~cm}$-once when the majority of plants were in the B stage, and again 2 wk later when a majority of plants were in preboot and postboot stages. This study supports Mosley's (1996) recommendation for grazing with sheep once in late spring and again when new inflorescences have developed, and concurs with similar findings by Tausch et al. (1994). In addition, it shows that clipping to $7.6 \mathrm{~cm}$ (3 inches) in a cheatgrass-dominated area, as recommended by Mosley (1996), is not always adequate.

Our study indicated that a single defoliation of $2.5 \mathrm{~cm}$ at the $P$ stage was also able to drastically reduce cheatgrass seed density. However, the P stage would not be a recommended time for grazing. The large number of viable seeds produced during the $\mathrm{P}$ stage creates a higher risk of dispersing viable seeds, particularly with livestock, because seeds disturbed at that time can dislodge and disperse. Our technicians attempted to collect seeds when they harvested the plants, whereas livestock would be more likely to disperse viable seeds, or avoid them altogether. As cheatgrass seeds mature, the preference of livestock for cheatgrass decreases, and risks of injury increase (Klemmedson and Smith 1964; Mosley 1996). Thus, we caution against grazing livestock during the $\mathrm{P}$ stage.

There is a lower risk of seeds dispersing during defoliations at the B stage because cheatgrass plants produced few viable seeds during this stage. These results are consistent with observational studies examining cheatgrass phenology and the use of prescribed grazing that generally recommend defoliating cheatgrass before its seed enters the soft "dough" stage to avoid viable seed production (Mosley 1996). Therefore, grazing treatments that defoliate cheatgrass multiple times before seed maturity begins at the $\mathrm{P}$ stage have the greatest potential for reducing cheatgrass populations.

Along with determining the optimal defoliation timing, intensity, and frequency, our second objective was to consider whether the reduction in seed density would be adequate as a sole seed-bed preparation technique for native reseeding projects. Plants surviving under the most successful treatment still produced from about 123 to 324 and 769 to 2256 seeds $\cdot \mathrm{m}^{-2}(95 \% \mathrm{CI})$ at the end of the season at Lincoln Bench and Succor Creek, respectively. Whether these densities are low enough to adequately reduce cheatgrass competition on native seedlings in the following year is uncertain. Few direct studies provide evidence for the level of cheatgrass density that will start to impair desired-plant establishment. However, an evaluation of the available evidence supports the premise that cheatgrass can be present at minimal densities and still allow 
successful establishment of native seedlings. Given that successful plant establishment is five native seedlings $\cdot \mathrm{m}^{-2}(0.5$ seedling $\cdot$ foot $^{-2}$; Hyder and Sneva 1954; Cook et al. 1967 [cited in Vallentine 1989]), and given that native perennial seed densities of 215 pure live seeds $\cdot \mathrm{m}^{-2}$ (20 seeds $\cdot$ foot $\left.{ }^{-2}\right)$ are often the recommended seeding rates in revegetation projects (Vallentine 1989), then successful establishment of native plants on sagebrush rangelands of the Intermountain West would require the survival of about $2.5 \%$ of the seeded density (Vallentine 1989). An observational study by Harris (1967) found that cheatgrass densities of 90 to 100,15 to 20 , and 0 to 4 plants $\cdot \mathrm{m}^{-2}$ were associated with $39 \%, 69 \%$, and $86 \%$ survival of bluebunch wheatgrass seedlings (Psendoroegneria spicata [Pursh] A. Love). In another study, field trials compared various cheatgrass control methods in conjunction with seedlings of a perennial grass mixture dominated by crested wheatgrass (Agropyron cristatum [L.] Gaertn.), a nonnative perennial (Hull and Stewart 1948). Plots retaining less than 100 cheatgrass plants $\cdot \mathrm{m}^{-2}$ the year following cheatgrass control treatments tended to have higher crested wheatgrass survival after $3 \mathrm{yr}$ than plots with greater than 100 plants $\cdot \mathrm{m}^{-2}$.

Given this evidence, cheatgrass densities slightly higher than 100 plants $\cdot \mathrm{m}^{-2}$ might still allow $2.5 \%$ survival of desirable species. For the purpose of discussing the effectiveness of a defoliation treatment, we will consider a maximum cheatgrass density of 300 plants $\cdot \mathrm{m}^{-2}$ in the year following a defoliation treatment as the level that would likely allow successful restoration of desired perennial species. Furthermore, because cheatgrass seed germinability can exceed $90 \%$ (Hulbert 1955; Young et al. 1969), seed densities should not exceed 330 viable seeds $\cdot \mathrm{m}^{-2}$. In our study, Lincoln Bench cheatgrass densities fell beneath our 330 seeds $\cdot \mathrm{m}^{-2}$ threshold, but Succor Creek densities were above this limit. Given these assumptions and our results, the evidence from our study suggests that a defoliation treatment could be effective as a sole cheatgrass control treatment under some situations in preparing a seed bed for native plant restoration. However, the apparent mechanisms by which cheatgrass plants overcame defoliation pressure in this study may make defoliations with actual livestock problematic.

Cheatgrass is able to germinate throughout the fall, winter, and spring-even as late as May (Mack and Pyke 1984; Young and Evans 1985)-thereby generating different cheatgrass cohorts of various sizes; earlier-germinating plants were generally larger than later-germinating plants. We observed high variability in cheatgrass developmental stages and heights among the primary stems of plants at the time of each treatment, suggesting multiple cheatgrass cohorts. The shorter or lessdeveloped plants were able to avoid defoliation, as was shown by some inflorescences being observed in every treatment $1 \mathrm{wk}$ following application and surviving plants of various phenologic stages being observed just before the second of the B treatments. Decumbent tillers may play a role in grazing avoidance by cheatgrass (Young and Evans 1985), and these were noted among harvested plants from Succor Creek. Although we attempted to count decumbent tillers (Mayer 2004), reliable counts were difficult to obtain and were not reported.

Cheatgrass plants may also have been able to recover from the defoliation treatments through asynchronous tiller development (Harris 1967), in which a plant's tillers may simultaneously occur at different stages of development. Following removal of the tallest tillers, shorter tillers may remain and continue in their development (Richards 1993). Grazing-tolerant plants, such as cheatgrass, may also rapidly produce and develop new tillers upon removal of the inflorescence, possibly through compensatory growth or existing carbon reserves (Laude 1957; Richards 1986). These traits are among those recognized as being important in other grazing-tolerant or grazing-avoidant range and pasture grasses (Neiland and Curtis 1956).

Variation in the timing of cheatgrass germination and development, decumbent stems, asynchronous tiller development, and production of new tillers may make effective control through livestock grazing a challenge. Calculations of livestock stocking rates based on the amount of cheatgrass biomass removed at each treatment provided an estimate that the levels of defoliations obtained here would hypothetically be able to support at least seven cow-calf pairs or 14 sheep $\cdot$ acre $^{-1} \cdot$ day $^{-1}$ at both sites in all treatments, although not in those treatments where clipping occurred at $7.5 \mathrm{~cm}$ at the B stage (Mayer 2004). However, given the variability in the development and heights of cheatgrass plants in this study-including the presence of decumbent stems-one obstacle in using livestock may occur in attempting to direct livestock to graze all of the cheatgrass plants in any given area. Livestock tend to be energy maximizers and will therefore feed optimally, selecting the most nutritious and easily accessible forage (Stuth 1991). Considering this, livestock would likely have to be confined in a relatively dense stocking level by using a fenced area to compel animals to graze all plants, including those less profitable to the animal. Even then an animal might refrain from grazing the available forage if it is obtained at too great a cost versus the benefit gained (Coleman et al. 1989). This possibility is of concern when the objective of grazing is for cheatgrass control, particularly for removal of very small plants. Singlestemmed, single-seeded plants less than $10 \mathrm{~cm}$ tall and with very little biomass were observed frequently in this study. Also, in the case of the Lincoln Bench treatment of two defoliations at $2.5 \mathrm{~cm}$ at the B stage (SB2), plants surviving (or emerging) from the first round of clipping produced smaller plants at the time of the second round, as indicated by the smaller amount of biomass removed (Table 3).

An individual cheatgrass plant would also be expected to respond differently to actual grazing than to clipping as was used in this study. Clipping cannot completely simulate grazing by animals. In a study of the effect of horse and sheep grazing on forage plants in the Himalayas, regrowth was better in clipped grasses than in grazed grasses (Negi et al. 1993), whereas other evidence indicates an increase in photosynthetic rates in grazed plants vs. mown plants (Wallace 1990). Some of the differences in plant response in studies using clipped or mown vs. grazed treatments may occur because clipping or mowing cannot account for the effects of trampling, nutrient recycling, diet selectivity, or the grazing characteristics of the animal. In addition, sheep may be more effective than our results indicate because they are capable of grazing to a stubble height of about $1 \mathrm{~cm}$ rather than $2.5 \mathrm{~cm}$, which was our shortest defoliation height. Thus, the recovery response of individual cheatgrass plants to grazing, and the ability of 
livestock to consistently remove small plants and decumbent tillers, would need to be measured closely in future grazing studies in light of our findings.

Variation in annual soil moisture and other environmental conditions are other possible factors that need to be considered. A year with greater moisture availability may improve the ability of plants to recover following defoliation-particularly if it should occur in the spring (Harris 1967; Richardson et al. 1989) - and may retard phenological development and thus lengthen the growing season. This may require a longer or an additional period of grazing depending partly on when additional precipitation occurs. Conversely, an increase in moisture availability could result in greater plant productivity and height (Klemmedson and Smith 1964), which would make all clipping treatments—or grazing-more effective by capturing more inflorescences. This study took place during a relatively dry growing season, and many cheatgrass plants had not reached $7.6 \mathrm{~cm}$ in height when clipping treatments were initiated. Different environmental conditions from site to site can also play a role in treatment success. Variable responses by cheatgrass at different sites, with different site potentials or weather, stress the importance of considering all factors that could affect cheatgrass survival and seed production from site to site and year to year, reinforcing the assertion by Mosley (1996) that grazing treatments should be "tailored to each site's unique combination of soil, plant, and animal variables."

There are several ways in which an animal defoliation treatment might be made more effective. Increasing defoliation intensity (e.g., to a stubble height of $1 \mathrm{~cm}$ with sheep) and keeping them on the site continuously and until cheatgrass would normally be entering the P stage might further decrease seed production provided that the overwhelming number of plants are defoliated before the P stage. This strategy would better capture any potential regrowth or new growth, but would require maintaining animals on the site for about $4 \mathrm{wk}$ based on the phenology observed during this study, and would depend on whether the site remained productive enough to support continuous grazing, or would require supplemental feeding. In addition, even a small persistent seed bank from the current or a previous year could require defoliation treatments to be repeated for two or more years (Finnerty and Klingman 1962), or require a combination of control treatments. Supplementary treatments could include the use of herbicides in the following year to remove a small but persistent cheatgrass population not substantial enough to graze, or a prescribed fire in the season before grazing to remove some of the seeds in the litter.

\section{MANAGEMENT IMPLICATIONS}

In two cheatgrass-dominated sites in the sagebrush-steppe ecosystem, intensive and repeated clipping treatments conducted during inflorescence development clearly caused a reduction in cheatgrass seed densities. However, these treatments were not able to completely prevent seed production because of the ability of cheatgrass to tolerate and avoid defoliation. Thus, seed densities fell under our projected goal at only one of the sites. These results bring into question the advisability of using livestock in native plant reseeding projects, where the specific aim is to remove cheatgrass competition and increase the potential for successful reestablishment of native plants through artificial seeding. In pursuing this control method further, four questions might be investigated: 1) whether livestock are able to achieve equal or greater seed reductions using the established parameters set in this study; 2) if so, what the range of environmental conditions would be for this treatment to be most effective; 3) whether using livestock would be practical for larger-sized projects; and 4) whether defoliation effectiveness could be improved by increasing the defoliation intensity, repeating the defoliation for at least $2 \mathrm{yr}$, and/or using an integrated weed management approach with other control methods such as herbicide application or burning. Further studies pinpointing the necessary level of cheatgrass control would also help clarify the practicality and effectiveness of using grazing as a step in the process of restoring native sagebrush steppe to cheatgrass-dominated regions of the Intermountain West, but we recommend that these incorporate information on the total seed densities of cheatgrass (seed banks and seed production), not merely dominance or density measures of adult plants.

\section{ACKNOWLEDGMENTS}

We thank J. Findley with the Bureau of Land Management, Vale, OR, for logistical support; M. Huso of the Quantitative Services Group of the College of Forestry at Oregon State University for statistical advice; M. Pellant, P. Doescher, and M. Wilson for aid in research design; and two anonymous peer reviewers during the US Geological Survey peer review process and one peer reviewer and the editors of Rangeland Ecology and Management.

\section{LITERATURE CITED}

Allcock, K., R. Nowak, B. Blank, T. Jones, T. Monaco, J. Chambers, R. Tausch, P. Doescher, V. Satyal, J. Tanaka, D. Ogle, L. St. John, M. Pellant, D. Pyke, E. SCHUPP, AND C. CALL. 2006. Integrating weed management and restoration on western rangelands. Ecological Restoration 24:199-200.

Association of Official Seed Analysts. 2002a. Rules for testing seeds. Las Cruces, NM, USA: Association of Official Seed Analysts. $166 \mathrm{p}$.

Association of Official Seed Analysts. 2002b. Seedling evaluation handbook. Las Cruces, NM, USA: Association of Official Seed Analysts. $128 \mathrm{p}$.

Beckstead, J., S. E. Meyer, and P. S. Allen. 1993. Effects of afterripening on cheatgrass (Bromus tectorum) and squirreltail (Elymus elymoides) germination. In: B. A. Roundy, E. D. McArthur, J. S. Haley, and D. K. Mann [eDs.]. Proceedings: wildland shrub and arid land restoration symposium. Ogden, UT, USA: US Department of Agriculture, Forest Service, General Technical Report INT-GTR-315. p. 165-172.

Booysen, P. De V., N. M. Tainton, And J. D. Scott. 1963. Shoot-apex development in grasses and its importance in grassland management. Herbage Abstracts 33:209-213.

Coleman, S. W., T. D. A. Forbes, and J. W. Stuth. 1989. Measurements of the plantanimal interface in grazing research. In: G. C. Martin [ED.]. Grazing research methods. Madison, WI, USA: American Society of Agronomy. p. 37-52.

Cook, C. W., AND L. E. HarRIS. 1952. Nutritive value of cheatgrass and crested wheatgrass on spring ranges of Utah. Journal of Range Management 5:331337.

Daubenmire, R. F. 1940. Plant succession due to overgrazing in the Agropyron bunchgrass prairie of southeastern Washington. Ecology 21:55-64.

Falloon, R. E. 1979. Seedling and shoot infection of Bromus catharticus by Ustilago bullata. Transactions of the British Mycological Society 73:49-56. 
Finnerty, D. W., And D. L. Klingman. 1962. Life cycles and control studies of some weed bromegrasses. Weeds 10:40-47.

FISHeR, G. W., AND C. S. Holton. 1957. Biology and control of the smut fungi. New York, NY, USA: Ronald Press. 622 p.

HaRrIs, G. A. 1967. Some competitive relationships between Agropyron spicatum and Bromus tectorum. Ecological Monographs 37:89-111.

Hulbert, L. C. 1955. Ecological studies of Bromus tectorum and other annual bromegrasses. Ecological Monographs 25:181-212.

Hull, A. C., JR., AND C. K. PearSE. 1943. How to reseed southern Idaho range lands. Ogden, UT, USA: US Department of Agriculture, Forest Service, Intermountain Forest and Range Experimental Station, Research Paper 2. 19 p.

Hull, A. C., JR., AND G. Stewart. 1948. Replacing cheatgrass by reseeding with perennial grass on southern Idaho ranges. Journal of the American Society of Agronomy 40:694-703.

Hyder, D. N., and F. A. Sneva. 1954. A method for rating the success of range seeding. Journal of Range Management 7:89-90.

Klemmedson, J. O., And J. G. Smith. 1964. Cheatgrass (Bromus tectorum L.). Botanical Review 30:226-262.

LAude, H. M. 1957. Growth of the annual grass plant in response to herbage removal. Journal of Range Management 10:37-39.

MAck, R. N. 1986. Alien plant invasion into the Intermountain West: a case history. In: H. A. Mooney and J. A. Drake [EDS.]. Ecological studies 58: ecology of biological invasions of North America and Hawaii. New York, NY, USA: Springer-Verlag. p. 191-213.

Mack, R. N., and D. A. PYke. 1984. The demography of Bromus tectorum: the role of microclimate, grazing and disease. Journal of Ecology 72:731-748.

MaYeR, K. H. 2004. The effects of defoliation on Bromus tectorum seed production and growth [MS thesis]. Corvallis, OR, USA: Oregon State University. $54 \mathrm{p}$.

Miller, R. F., T. J. Svejcar, and N. E. West. 1994. Implications of livestock grazing in the Intermountain sagebrush region: plant composition. In: M. Laycock, W. A. Pieper, and R. D. Vavra [EDS.]. Implications of livestock herbivory in the West. Denver, C0, USA: Society of Range Management. p. 101-146.

Mostey, J. C. 1996. Prescribed sheep grazing to suppress cheatgrass: a review. Sheep and Goat Research Journal 12:74-81.

Negi, G. C. S., H. C. Rikhari, and S. P. Singh. 1993. Plant regrowth following selective horse and sheep grazing and clipping in an Indian central Himalayan alpine meadow. Arctic and Alpine Research 25(3):211-215.

Nelland, B. M., And J. T. CuRtis. 1956. Differential response to clipping of six prairie grasses in Wisconsin. Ecology 37:335-365.

Pellant, M. 1990. The cheatgrass-wildfire cycle-are there any solutions? In: E. D. McArthur, E. M. Romney, S. D. Smith, and P. T. Tueller [eds.]. Proceedings-symposium on cheatgrass invasion, shrub die-off, and other aspects of shrub biology and management. Ogden, UT, USA: US Department of Agriculture, Forest Service, Intermountain Research Station, General Technical Report INT-Z76. p. 11-18.

Pellant, M., and C. Hall. 1994. Distribution of two exotic grasses on intermountain rangelands: status in 1992. In: S. B. Monsen and S. G. Kitchen [EDS.]. Proceedings-ecology and management of annual rangelands. Ogden, UT, USA: US Department of Agriculture, Forest Service, General Technical Report INT-GTR-313. p. 109-112.

PYke, D. A. 1983. Demographic responses of Bromus tectorum and seedlings of Agropyron spicatum to grazing by Cricetids [PhD dissertation]. Pullman, WA, USA: Washington State University. $112 \mathrm{p}$.

PYkE, D. A. 1986. Demographic responses of Bromus tectorum and seedlings of Agropyron spicatum to grazing by small mammals: occurrence and severity of grazing. Journal of Ecology 74:739-754.

PYke, D. A. 1987. Demographic response of Bromus tectorum and seedlings of Agropyron spicatum to grazing by small mammals: the influence of grazing frequency and plant age. Journal of Ecology 75:825-835.

Pyke, D. A. 1994. Ecological significance of seed banks with special reference to alien annuals. In: S. B. Monsen and S. G. Kitchen [EDS.]. Proceedings- ecology and management of annual rangelands. Ogden, UT, USA: US Department of Agriculture, Forest Service, General Technical Report INT-GTR313. p. 197-201.

Pyke, D. A., AND S. J. Novak. 1994. Cheatgrass demography-establishment attributes, recruitment, ecotypes, and genetic variability. In: S. B. Monsen and S. G. Kitchen [EDS.]. Proceedings-ecology and management of annual rangelands. Ogden, UT, USA: US Department of Agriculture, Forest Service, General Technical Report INT-GTR-313. p. 12-21.

RICHARDS, J. H. 1986. Plant response to grazing: the role of photosynthetic capacity and stored carbon reserves. In: P. J. Joss, P. W. Lynch, and O. B. Williams [EDS.]. Rangelands: a resource under siege. Proceedings of the Second International Rangeland Congress. New York, NY, USA: Cambridge University Press. p. 428-430.

Richards, J. H. 1993. Physiology of plants recovering from defoliation. In: M. J. Baker [ED.]. Grasslands for our world. Wellington, New Zealand: SIR Publishing. p. 46-54.

Richardson, J. M., D. R. Gealy, and L. A. Morrow. 1989. Influence of moisture deficits on the reproductive ability of downy brome (Bromus tectorum). Weed Science 37:525-530.

SANDERS, K. D. 1994. Can annual rangelands be converted and maintained as perennial grasslands through grazing management? $I n$ : S. B. Monsen and S. G. Kitchen [EDS.]. Proceedings-ecology and management of annual rangelands. Ogden, UT, USA: US Department of Agriculture, Forest Service, General Technical Report INT-GTR-313. p. 412-413.

SAS [computer program]. 1999. Version 8.2 for Windows. Cary, NC, USA: SAS Institute Inc.

PRISM Group. 2004. Oregon State University. Available at: http://www.prismclimate. org, created 23 March 2004. Accessed 3 December 2007.

Stark, R. H., J. L. Toevs, and A. L. Hafenrichter. 1946. Grasses and cultural methods of reseeding abandoned farmlands in southern Idaho. Moscow, ID, USA: Agricultural Experiment Station, Bulletin No. 267. 36 p.

Stuth, J. W. 1991. Foraging behavior. In: R. K. Heitschmidt and J. W. Stuth [eds.]. Grazing management: an ecological perspective. Portland, OR, USA: Timber Press. p. 65-84.

Tausch, R. J., R. S. Nowak, A. D. Bruner, and J. Smithson. 1994. Effects of simulated fall and early spring grazing on cheatgrass and perennial grass in western Nevada. In: S. B. Monsen and S. G. Kitchen [EDS.]. Proceedings-ecology and management of annual rangelands. Ogden, UT, USA: US Department of Agriculture, Forest Service, General Technical Report INT-GTR-313. p. 113-119.

Vallentine, J. F. 1989. Range development and improvements. 3rd edition. San Diego, CA, USA: Academic Press. 524 p.

Vallentine, J. F., And A. R. Stevens. 1994. Use of livestock to control cheatgrass a review. In: S. B. Monsen and S. G. Kitchen [EDS.]. Proceedings-ecology and management of annual rangelands. Ogden, UT, USA: US Department of Agriculture, Forest Service. General Technical Report INT-GTR-313. p. 202-206.

Wallace, L. L. 1990. Comparative photosynthetic responses of big bluestem to clipping versus grazing. Journal of Range Management 43:58-61.

WEST, N. E. 1983. Western intermountain sagebrush steppe. In: West, N. E [ED.]. Temperate deserts and semi-deserts. Amsterdam, The Netherlands: Elsevier Scientific Publishing. p. 351-373.

Whisenant, S. G. 1999. Repairing damaged wildlands. New York, NY, USA: Cambridge University Press. $312 \mathrm{p}$.

Young, J. A., And R. A. Evans. 1975. Germinability of seed reserves in a big sagebrush community. Weed Science 23:358-364.

Young, J. A., and R. A. Evans. 1985. Demography of Bromus tectorum in Artemisia communities. In: J. White [ED.]. The population structure of vegetation. Boston, MA, USA: Dr. W. Junk Publishers. p. 283-289.

Young, J. A., R. A. Evans, and R. E. ECKert, JR. 1969. Population dynamics of downy brome. Weed Science 17:20-26. 